Bartłomiej SIEK, Adam SZARSZEWSKI

Gdański Uniwersytet Medyczny

\title{
Vitae medicorum Gedanensium - rękopis z połowy XVIII w. ze zbiorów Biblioteki Gdańskiej Polskiej Akademii Nauk
}

Jednym z najciekawszych archiwaliów dotyczących dziejów medycyny gdańskiej jest przechowywany w Bibliotece Gdańskiej Polskiej Akademii Nauk rękopis o sygnaturze Ms514. Źródło zawiera życiorysy lekarzy gdańskich, stanowiąc obecnie zbiór informacji nie do przecenienia. Do chwili obecnej informacje zawarte w manuskrypcie stały się podstawą licznych opracowań, zarówno o charakterze biograficznym ${ }^{1}$, jak i prac związanych z dziejami nauki i kultury gdańskiej². Wydaje się, że z powodu wartości merytorycznej oraz nienajlepszego stanu zachowania źródła powinno ono zostać w najbliższym czasie opublikowane. Pozwoli to zarówno na lepsze wykorzystanie go w badaniach historycznych, jak i na uchronienie samego rękopisu od dalszej dewastacji. Koniecznym wydaje się także przeprowadzenie digitalizacji rękopisu w celu umożliwienia korzystania z tego źródła wielu badaczom, bez zagrożenia jego uszkodzeniem.

Pochodzący z biblioteki Valentina Schlieffa ${ }^{3}$ rękopis nosi tytuł Vitae medicorum Gedanensium, qui tum apud suos tum apud exteros floruerunt. Autor (przynajmniej części biogramów) nie jest osobą anonimową. Krótka notatka na wstępie, kreślona ręką V. Schlieffa, wskazuje jednoznacznie na osobę Ludwiga von Hammena, gdańszczanina. Ponadto dalsza część rękopisu zawiera także jego autobiografię (Personalia Ludwig von Hammen, Medicinae Doctoris von ihm selbst abgefasset), dodatkowo zaś dr L. von Hammen wszedł do historii medycyny, kojarzony z pewnym doniosłym odkryciem naukowym.

\footnotetext{
${ }^{1}$ Np. Altpreußische Biographie, hrsg. K. Forstreuter, F. Gause, Ch. Krollmann, E. Bahr, G. Brausch, t. 1-4, KönigsbergMarburg 1936-1989; F. Schwarz, Verzeichnis der Danziger Ärzte. I. 16. Jahrhundert, „Danziger familiengeschichtliche Beiträge”, 4, 1939, s. 27-36; F. Schwarz, Danziger Ärzte im 16.-18. Jahrhundert, Teil 2: 1600-1651, „Danziger familiengeschichtliche Beiträge”, 5, 1940, s. 21-32; F. Schwarz, Danziger Ärzte im 16.-18. Jahrhundert, Teil 3: 1651-1699, „Danziger familiengeschichtliche Beiträge", 6, 1941, s. 13-22; Słownik biograficzny Pomorza Nadwiślańskiego, red. St. Gierszewski, Z. Nowak, Gdańsk 1992-1997; PSB, t. 1-, Kraków 1935-.

${ }^{2} \mathrm{~Np}$. H. Freytag, Die Preussen auf der Universität Wittenberg und die nichtpreussischen Schüler Wittenbergs in Preussen von 1502 bis 1602, Leipzig 1903; E. Loth, Gdańska szkoła anatomiczna (1584-1812), „Archiwum historji i filozofji medycyny oraz historji nauk przyrodniczych”, 8, 1928, s. 1-20, 208-228; S. Sokół, Historia gdańskiego cechu chirurgów 1454-1820, Wrocław 1957; S. Sokół, Medycyna w Gdańsku w dobie Odrodzenia, Wrocław 1960; T. Grzybkowska, Andrzej Stech: malarz gdański, Gdańsk 1979; D. van Stekelenburg, Michael Albinus „Dantiscanus” (1610-1653): eine Fallstudie zum Danziger Literaturbarock, Amsterdam 1987; M. Pawlak, Studia uniwersyteckie młodzieży z Prus Królewskich w XVIXVIII w., Toruń 1988; A. Szarszewski, M. Bogotko-Szarszewska, Auditorium Anatomicum and Theatrum Anatomicum in Gdańsk, „Folia Morphologica”, 73, 2014, nr 3, s. 239-246.

3 Valentin Schlieff (1680-1750), historyk, bibliograf, badacz dziejów Gdańska. M. Sławoszewska, Gdańska 'Bibliotheca Archivi', „Archeion”, 40, 1964, s. 134-135; M. Babnis, Schlieff Walenty, w: Słownik biograficzny Pomorza Nadwiślańskiego, t. 4, red. Z. Nowak, Gdańsk 1997, s. 160 n.
} 
Ludwig von Hammen urodził się 31 VIII 1651 r. w Gdańsku. Ojcem był Johann von Hammen, matką Adelgunda z domu Ricci, córka syndyka Christopha Ricciego. Ojciec zmarł, gdy Ludwig miał zaledwie 7 lat. Chłopiec uczęszczał początkowo do szkoły mariackiej, a następnie od 1661 r. do Gdańskiego Gimnazjum Akademickiego. W 1671 r. zgodnie z obyczajem epoki L. von Hammen wyruszył w naukową podróż po Europie. Odwiedził Kopenhagę, Amsterdam, Utrecht, Lejdę, Delfty, Londyn, Oxford, Antwerpię, Brukselę, Paryż, a także Montpellier, gdzie się doktoryzował w 1674 r. Następnie przebywał w Genui, Rzymie oraz Bolonii. Do Gdańska powrócił w 1676 r. Rok później (4 IV 1677 r.) ożenił się z dwudziestoletnią Concordią Dilger, córką pastora kościoła Mariackiego, Nathanaela Dilgera (1604-1679), która wkrótce zmarła (pochowana w kościele Mariackim 5 XI 1677 r.). W 1678 r. został lekarzem nadwornym króla Jana III Sobieskiego, a w 1683 r. lekarzem załogi twierdzy Wisłoujście. Był nie tylko doktorem medycyny, ale także chirurgiem, co w owych czasach należało do rzadkości. Opowiadał się przy tym za uczynieniem z chirurgii pełnoprawnej gałęzi medycyny, co stanowiło źródło kontrowersji pomiędzy nim a słynnymi lekarzami epoki. Wykonywał obdukcje i sekcje zwłok, między innymi sekcję publiczną 6 III 1679 r., czy też, wraz z dr. Johannesem Schmiedtem (1623-1690), swoim przyjacielem i powinowatym ${ }^{4}, 4$ VIII 1684 r. obdukcję zwłok opata Adama Trebnica. Zmarł po krótkotrwałej chorobie 15 III 1689 r. w wieku niespełna trzydziestu ośmiu lat. Pochowany został 23 III 1689 r. w kościele Mariackim5.

Powyższe informacje pochodzą w przeważającej części ze wspomnianego autobiogramu Ludwiga von Hammena. Niestety, nie jest to manuskrypt pisany ręką samego zainteresowanego. Ludwig von Hammen doprowadził swój biogram do objęcia przezeń urzędu lekarza twierdzy Wisłoujście 23 II 1683 r., natomiast źródło zawiera i dalsze losy uczonego, pisane tą samą ręką. Zaczynają się one od słów: So weit des Seel. D[octoris?] einige Worte. Was nun seinen geführten Wandel u[nd] Christenthum betrifft ist in der Stadt genugsam bekandt wie daß Er seinem Beruff fleißig abgewartet hat etc. ${ }^{6}$ Autor uzupełnienia biogramu podkreślił w obszernych wywodach zasługi zmarłego, zwłaszcza względem pacjentów. Opisał też pokrótce ostatnie dni lekarza, skupiając się szczególnie na pobożnym, godnym chrześcijanina pożegnaniu się z tym światem. Jednocześnie część ta niemal nic nie wnosi do wiedzy na temat biografii Ludwiga von Hammena, jakby jej autor nie posiadał żadnych dokładnych danych. Jedynie relacja dotycząca okoliczności śmierci sprawia wrażenie relacji z pierwszej ręki, a sposób opisu sugeruje, iż uczynił to lekarz.

W powszechnej historii medycyny L. von Hammen zapisał się jako rzekomy odkrywca męskich gamet w nasieniu. Miałoby się to zdarzyć w 1677 r., w czasie naukowej podróży po Europie, kiedy to w Lejdzie zetknął się jakoby z wynalazcą mikroskopu Antoniem van Leeuwenhoekiem. Zainspirowany przez holenderskiego badacza podobno nie tylko zbadał świeże nasienie, ale także monitorował ewolucję zmian w nim zachodzących. Wiele jednak wskazuje na to, iż nie jest to prawdą. Trudno bez szczegółowych badań rozstrzygnąć o źródle nieporozumienia (o ile ma ono rzeczywiście miejsce). Walther Schönfeld wskazuje na samego Albrechta von Hallera, który w jednym ze swych dzieł wymienia Ludwiga von Hammena: (...) Gedanensis, vermiculorum spermaticorum inventor ab anno 16777. Wielki uczony, zdaniem W. Schönfelda, nadinterpretował zachowane źródła, uznając innego lekarza o nazwisku „Ham” za tożsamego z Ludwigiem von Hammenem ${ }^{8}$ Idąc jego śladem, większość

\footnotetext{
${ }^{4}$ Matka Ludwiga von Hammen i żona Johannesa Schmiedta były siostrami; F. Schwarz, Danziger Ärzte, Teil 2, s. 26.

${ }^{5}$ Biblioteka Gdańska Polskiej Akademii Nauk [dalej: Bibl. Gd. PAN], Ms 514, s. 215-226; Ms 1355a, k. 10v; A. Bythner, Freuden-Gedichte auff den hochzeitlichen Ehrentag des H. Johann von Hammen und Adelgunde Riccin, Andreas Petermanns Witwe, Danzig 1650; Ch.G. Jöcher, Allgemeines Gelehrten-Lexicon, t. 2, Leipzig 1750, kol. 1343; W. Schönfeld, Um die Entdeckung der menschlichen Samenfäden, „Archiv für Dermatologie und Syphilis”, 178, 1938, s. 358-362; F. Schwarz, Danziger Ärzte, Teil 3, s. 13; A. Selling, Deutsche Gelehrten-Reisen nach England, 1660-1714, Frankfurt a. Main, New York 1990, s. 271; M. Gliński, J. Kukliński, Kronika Gdańska 997-1997, t. 1, Gdańsk 1998, s. 94, 288.

${ }^{6}$ Bibl. Gd. PAN Ms 514, s. 223.

7 A. von Haller, Bibliotheca anatomica: qua scripta ad Anatomen et Physiologiam facientia a rerum initiis recensentur, t. 1 , Tiguri 1774, s. 678.

8 W. Schönfeld, Um die Entdeckung, s. 358-362; F. Schwarz, Danziger Ärzte, Teil 3, s. 13.
} 
autorów podawała za odkrywcę gamet męskich gdańszczanina, co ugruntowane zostało przez Kurta Sprengela w jego monumentalnej historii nauk lekarskich oraz Heinricha Haesera w podręczniku do dziejów medycyny9 . Pierwsze poważne zastrzeżenia zgłosił dopiero H.J. Halbertsma w 1864 r., identyfikując odkrywcę plemników z Johannesem Hamem z Arnhem ${ }^{10}$. Podobnie W. Schönfeld w 1938 r. w oparciu o szczegółową analizę źródeł umocnił pogląd, iż arnhemczyk Ham i gdańszczanin Hammen to dwie różne osoby ${ }^{11}$. Swoją drogą Ludwigowi von Hammenowi nowy instrument badawczy mikroskop - nie był obcy. Ludwig von Hammen bez wątpienia użył go w Gdańsku do badania zajętych procesem chorobowym tkanek gruczołu krokowego jednego $\mathrm{z}$ jego pacjentów ${ }^{12}$; inspirację do tego stanowiły zapewne nauki pobierane w Bolonii w 1674 r. u Marcella Malpighiego ${ }^{13}$.

Pozostawiając na boku powyższą kwestię, należy dodać, iż L. von Hammen jest autorem szeregu traktatów medycznych, z których przynajmniej trzy (rozprawa doktorska, rozprawa o przepuklinach oraz biogramy lekarzy gdańskich) zachowały się do tej pory. Źródła wymieniają:

1. Gymnasma Philosophicum de Pavone, thematis loco elaboratum, Praeside Georgio Neufeldt, Gedani 1668 ;

2. Quaest[io] med[ica] An in lue venerea Hydrargyrum Guaiaco preferendum. [In:] Curriculum Medicum Monspeliense, academicis exercitationibus pro Doctoratus Gradu obtinendo publice institutum, Monspelli 1674;

3. Dissertatio Academica de Herniis. Accedunt Epistolae et Responsiones ad Carolum Drelincurtium de Crocodillo ac mendaci Vesicae calculo, Gedani 1677;

4. Vires, usus, pondus medicamentorum, quae in officina pharmaceutica Gedanensi Martini Gerbricht, sub insigne Coronae aureae parato et in Poloniam missa pro Illustrissimis atque Magnificis Dominis, Dn. Palatino Lublinensi etc. etc. et Dno Stephano Stanislao à Czarnca Czarnecki, Generali Campestri exercituum Regni Notario, Kanjoviensi etc. etc. Capitaneo consignata à Ludovico von Hammen Ph. et Med D.S.R.M. Polon. Consiliario Medico, Latino-Poloniae, Gedani 1680 ;

5. Tractatus de Medicis Gedanensibus (w rękopisie) ${ }^{14}$.

Ludwig von Hammen, poza opracowaniem biogramów lekarzy gdańskich, był wedle informacji przekazanej przez Henninga Wittego ${ }^{15}$ autorem jeszcze jednego dzieła tego typu — kontynuacji i rozwinięcia popularnego w tym czasie kompendium bio-bibliograficznego Johannesa Antonidesa van der Lindena (1609-1664). Autor ten był wybitnym uczonym, dla swej erudycji zwanym ,philologus

\footnotetext{
${ }^{9}$ K. Sprengel, Versuch einer pragmatischen Geschichte der Arzneykunde, t. 4, Halle 1801, s. 293; H. Haeser, Lehrbuch der Geschichte der Medicin und der Volkskrankheiten, Jena 1845, s. 528. Ten ostatni podaje, jakoby L. von Hammen miał pochodzić ze Szczecina. Informację tę powtarza w drugim wydaniu (Jena 1853, t. 1, s. 579), a koryguje w wydaniu trzecim (Geschichte der Medizin und der epidemischen Krankheiten, Jena 1881, t. 2, s. 334) przywołując ustalenia H.J. Halbertsmy. ${ }^{10}$ H.J. Halbertsma, Johannes Ham von Arnhem, Entdecker der Spermatozoiden, w: Archiv für die Holländischen Beiträge zur Natur- und Heilkunde, hrsg. F.C. Donders, W. Berlin, t. 3, Utrecht, 1864, s. 322-326.

${ }^{11}$ Księga wpisów do Gimnazjum została wydana drukiem: W. Schönfeld, Um die Entdeckung, passim. Warto odnotować, że w księdze immatrykulacyjnej Gdańskiego Gimnazjum Akademickiego, Ludwig von Hammen widnieje jako Ludwig von Hamm - W. Schönfeld, Um die Entdeckung, s. 364.

${ }_{12}$ L. von Hammen, De crocodilo ac vesicae mendaci calculo epistolae Quibus additae V.C. Joannis Nicolai Pechlini, M. D. \& P.P. Responsoriae, Dantisci 1679, s. 13: „Sed mendacis calculi Historiam quam texere nuper coepi prosequor. Ramenta, quae iteratò extrahere necesse habui, microscopio examinata, impurioris salis figuras intertextis fibrillis tenuissimis exactè referunt" (Bibl.Gd.PAN XIXq, 79', 26). To samo w: L. van Hammen, De herniis dissertatio Academica. Accedunt de Crocodilo ac vesicae mendaci calculo epistolae et responsiones ad Magnificum atque Excellentissimum D. Carol. Drelincurtium Medicum Regium \& Professorem Primarium Lugd. in Bat. longè Celeberrimum, Lugduni Batavorum 1681, s. 130. S. Sokół, Historia chirurgii w Polsce, cz. 1, Chirurgia okresu cechowego, Wrocław 1967, s. 233-235.

${ }_{13}$ Marcello Malpighi (1628-1694), lekarz, biolog, twórca anatomii mikroskopowej. Jako pierwszy wykorzystał mikroskop do badania narządów. O studiach L. von Hammena u włoskiego uczonego por. Bibl. Gd. PAN Ms 514, s. 222.

${ }_{14}$ Bibl. Gd. PAN Ms514, s. 226. Tenże wykaz podany również w: W. Schönfeld, Um die Entdeckung, s. 366 n.; autor zwraca ponadto uwagę, iż zachował się także rękopis zawierający wyniki obdukcji zwłok opata Adama Trebnica (obecnie Bibl. Gd. PAN Ms 1355a, k. 10).

${ }^{15}$ H. Witte, Diarii biographici tomus secundus, Rigae 1691, s. 162.
} 
medicus". Studiował literaturę klasyczną i medycynę na uniwersytecie w Lejdzie, zaś sławę zawdzięcza przede wszystkim swojemu dziełu bibliograficznemu De scriptis medicis libri duo, Amstelredami $1637^{16}$. To właśnie opracowanie stało się inspiracją dla gdańskiego lekarza. Trudno powiedzieć, na ile L. von Hammen zamierzał jedynie przeredagować dzieło J. A. van der Lindena, zwłaszcza uzupełniając je o informacje dotyczące gdańszczan, na ile zaś miała to być samodzielna, pełna kontynuacja kompendium. Niemniej już sam zamysł pozwala przypuszczać, że zainteresowanie Ludwiga von Hammena biografistyką miało poważniejszy charakter.

Pierwszą księgę De scriptis medicis... J. A. van der Lindena stanowi wykaz lekarzy i ich dzieł uporządkowany alfabetycznie wedle imion; drugą księgę stanowią indeksy (niestety, nie podające numerów stron): przedmiotowy (kolejnym działom medycyny przyporządkowano nazwiska autorów prac z ich zakresu) i osobowy ułożony nazwiskami lekarzy. Bibliograficzne dzieło J. A. van der Lindena było za jego życia wydane trzykrotnie w Amsterdamie (1637, 1651, 1662), a w dwanaście lat po jego śmierci ukazało się wydanie czwarte, zatytułowane Lindenius renovatus ${ }^{17}$, które opracował Georg Abraham Mercklin ${ }^{18}$.

Kolejne wydania były uzupełniane o bieżące dane dotyczące publikacji z zakresu medycyny, a także o opisy prac pominiętych we wcześniejszych wydaniach. Praca holenderskiego uczonego zawiera niektóre dane, głównie bibliograficzne, dotyczące gdańskich lekarzy. Pierwsze wydanie notuje dwanaście nazwisk lekarzy gdańskich znanych ze słownika L. van Hammena (Daniel Beckherus, Laurentius Eichstadius, Severinus Göbelius, Petrus Kirstenius, Nicolaus Kleinfeld, Samuel Macovius, Michael Meierus, Henricus Neuhusius, Joachimus Oelhafius, Johannes Platocomus, Alexander à Suchten, Franciscus Tidicaeus - o ile nie zaznaczono inaczej, nazwiska wymieniono w brzmieniu przyjętym w słowniku Hammena), spośród których tylko pięciu (D. Beckherus, N. Kleinfeld, H. Neuhusius, J. Oelhafius, F. Tidicaeus) jest w dziele J. A. van der Lindena określonych gdańszczanami. W drugim wydaniu dochodzą trzy kolejne nazwiska (Andreas Knöfelius, Johannes Ernest Scheffler, Samuel Schoenborn), z których żadne nie zostało uzupełnione dopowiedzeniem łączącym lekarza z Gdańskiem. W wydaniu trzecim pojawia się pięć kolejnych nazwisk (Petrus Ianichius, Henricus Martini, Nicolaus Oelhafius, George Seger, Johann Warismanus), z których trzy (P. Ianichius, H. Martini, J. Warismanus) uzupełnione są dopiskiem „Dantiscanus”. W wydaniu czwartym jedno nazwisko (H. Neuhusius) znika, a pojawia się kolejnych pięć (Johann Jacob Doebelius, Ludovicus von Hammen, Johann Abraham a Gehema, Christian Rudnick, Petrus Spechtius), ale żaden z tych lekarzy nie jest nazwany gdańszczaninem ${ }^{19}$. Do powątpiewania w wiarygodność informacji przekazanej przez $\mathrm{H}$. Wittego skłania także fakt, że czwarte wydanie De scriptis medicis... zawiera nazwiska pięciu lekarzy związanych z Gdańskiem (Jacobus Barnerus, Jacobus Breynius, Israel Conradus, Ernestus Gothofredus Heyseus, Johannes Laderus — nazwiska w brzmieniu przyjętym w Lindenius renovatus), których słownik Ludwiga von Hammena nie notuje. Dwaj spośród tych lekarzy zostali określeni jako gdańszczanie: E.G. Heyseus jako Dantiscanus i J. Laderus jako Gedanensis.

\footnotetext{
${ }^{16}$ G. Sarton, Johannes Antonides van der Linden (1609-1664): medical writer and bibliographer, w: Science, medicine and history: essays on the evolution of scientific thought and medical practice written in honour of Charles Singer, coll. and ed. E. Ashworth Underwood, London 1953, s. 3-20.

${ }^{17}$ Lindenius renovatus, sive Johannis Antonidae van der Linden De scriptis medicis libri duo, quorum prior omnium, tam veterum quam recentiorum, Latino idiomate typis unquam expressorum scriptorum medicorum consumatissimum catalogum continet [...] a Georgio Abrahamo Mercklino, Norimbergae 1686.

${ }_{18}$ G.A. Mercklin (1644-1702), studiował medycynę w Altdorfie, jako lekarz praktykował w Norymberdze; por. George Sarton, Johannes Antonides van der Linden, s. 10 n. oraz hasło w Allgemeine Deutsche Biographie: August Hirsch, Mercklin, Georg Abraham <URL: http://www.deutsche-biographie.de/pnd115376038.html?anchor=adb> [dostęp: 31.03.2014].

${ }_{19} \mathrm{O}$ dziele J.A. van der Lindena jako źródle do dziejów medycyny polskiej por. S. Szpilczyński, Wkład Polski do nauk lekarskich w XVI-XVII w. w świetle bibliograficznego dzieła Jana Antoniego van der Lindena: De scriptis medicis, „Archiwum Historii Medycyny”, 41, 1978, nr 3, s. 333-357.
} 
Sam J. A. van der Linden nie wymienia nazwiska L. von Hammena pośród autorów, z których prac korzystał, lub osób, które nadsyłały uzupełniania do kolejnych wydań ${ }^{20}$. Jako autor ujęty w De scriptis medicis... L. von Hammen pojawia się dopiero w czwartym wydaniu, a wymieniona jest przy jego nazwisku jedna tylko praca: De herniis dissertatio academica [...]. Lugduni Batavorum 1681.

Przechowywany w Bibliotece Gdańskiej Polskiej Akademii Nauk, opatrzony sygnaturą Ms514, osiemnastowieczny papierowy rękopis w części związanej z osobą Ludwiga von Hammena stanowi twór niejednolity, napisany przez dwie osoby, o czym jeszcze szerzej będzie mowa. Opis katalogowy (Ludovici von Hammen vitae medicorum Gedanensium, qui tum apud suos tum apud exteros floruerunt) jest przy tym mylący, bowiem zachowany manuskrypt nie wyszedł spod ręki Ludwiga von Hammena. Przejęta do drukowanego katalogu rękopisów Biblioteki Gdańskiej PAN notatka Valentina Schlieffa, umieszczona przed właściwym słownikiem, dostarcza informacji o okolicznościach powstania rękopiśmiennego słownika biograficznego lekarzy gdańskich: „Anno 1721 ineunte D. Godofredus Stüve Medicus et Physicus in Patria communicavit mihi Ludovici von Hammen, Medici Regii Polonici et in Patria Practici Anno 168915 Martii demortui Vitas medicorum Gedanensium, qui tum apud suos tum apud exteros floruerunt. Illud ipsum exemplar postea in manus Dn. D. Breyn pervenit, qui illud describi curavit, e[x] quo $\mathrm{M}[\mathrm{anu}] \mathrm{s}[\mathrm{crip}]$ to praesens desumptum est, et sequentia sunt nomina illorum medicorum, qui vel plenius descripti vel saltem nominati sunt".

Pierwsza ręka, starsza, przepisująca przede wszystkim dzieło Ludwiga von Hammena, nie została zidentyfikowana. Druga, młodsza, stawiająca niejednokrotnie dopiski do tekstu starszego, należy do V. Schlieffa. Jak wynika z nakreślonej przezeń przedmowy, manuskrypt znajdował się jakiś czas w rękach dr. Johanna Philipa Breyna (1680-1764) ${ }^{21}$. Valentin Schlieff dowiedział się o jego istnieniu w 1721 r. od innego lekarza, Gottfrieda Stüvego (1664-1729), siostrzeńca Ludwiga von Hammena ${ }^{22}$. Prawdopodobnie zaraz potem rękopis znalazł się w posiadaniu V. Schlieffa, gdyż prowadzone pierwszą ręką zapiski urywają się na 1719 r., a dalsze prowadzone są ręką samego V. Schlieffa, aż do 1744 r. Przez ostatnie sześć lat swego życia V. Schlieff nie kontynuował już dzieła Ludwiga von Hammena. Wzmianki w tekście, które umożliwiałyby dokładniejsze datowanie, są bardzo nieliczne. W biogramie Teophilusa Homodeusa (s. 49) zawarta jest zapisana pierwszą ręką informacja: nunc Physicus Dantiscanus Primarius, drugą ręką nad podkreślonym słówkiem nunc dopisano: circa annum 1626. Więcej można wywnioskować z zapisanej pierwszą ręką informacji w biogramie Daniela Blancka (s. 162), która brzmi: nunc Thorunii senex vivit. Można zatem przyjąć, że partie tekstu zapisane pierwszą ręką musiały powstać przed 1691 r., wtedy bowiem zmarł Daniel Blanck wymieniony jako żyjący w Toruniu, a po 1647 r., gdy uzyskał on doktorat (jest określony w treści biogramu spisanej pierwszą ręką jako Doctor Patavinus). Drugą ręką zaś zapisane są informacje, wedle których przed zamieszkaniem w Toruniu był wezwany na dwór królewski za panowania Michała Korybuta, a zatem po 1669 r.

Zachowany słownik jest zatem odpisem słownika Ludwiga von Hammena dokonanym na polecenie dr. Johanna Philipa Breyna. Odpis ten był już częściowo uzupełniany, bowiem pierwsza ręka przywołuje w biogramie Benjamina Ewaldta (s. 194) publikacje, które ukazały się drukiem po śmierci L. von Hammena. Valentin Schlieff w wielu miejscach uzupełniał informacje zawarte w biogramach, a ponadto dołączył do słownika Ludwiga von Hammen spis treści, indeks, oraz trzy dodatkowe wykazy: Verzeichniss der Physicorum in Dantzig, Collectanea de Medicis Gedanensibus oraz Recensio

\footnotetext{
${ }^{20} \mathrm{~W}$ wydaniu pierwszym wymienione są następujące nazwiska: Conrad Gesner, Johann Georg Schenckius, Israel Spachius, Paschalis Gallus; w wydaniu drugim pojawiają się: Claudius Doresmieux, Robert Farvacius, Petrus Neurat, Nicolaus de Witte; w trzecim — Guido Patinus, Johann van Horne, Carolus Offredus, Gabriel Clauderus, Theodorus Colbius, Conrad van Hoeven.

${ }^{21}$ Johann Philip Breyn studiował w Leidzie w latach 1699-1702, gdzie się doktoryzował. Do Gdańska powrócił w 1704 r., tamże posiadał praktykę lekarską oraz prowadził badania botaniczne. F. Schwarz, Danziger Ärzte im 16.-18. Jahrhundert, Teil 3, s. $18 \mathrm{n}$.

${ }^{22}$ Matką Gottfrieda Stüve była Anna Stüve z domu von Hammen. On sam studiował od 1685 r. w Królewcu, potem w Lejdzie, gdzie w 1691 się doktoryzował. W 1700 r. został fizykiem miejskim w Gdańsku. Stüve ożenił się w 1694 r. ze swą kuzynką, Virginią Renatą, córką dr. Johanna Schmiedta i Anny Riccius. F. Schwarz, Danziger Ärzte, Teil 3, s. 14 n.
} 
Doctorum Medicinae, qui Gedani vixerunt, vel ibidem nati sunt, quorum Parentes Verbi Divini Ministri fuerunt. O rozbudowaniu wersji dzieła Ludwiga von Hammen świadczy też układ spisu treści, w którym po biogramie oznaczonym liczbą porządkową 74 (Joannes Gabriel Schmiedt, s. 178) na początku kolejnej strony następuje zdanie: Accesserunt huic operi Hammeniano Vitae integrae vel aliquales sequentium Dantiscanorum medicorum, a po nim osiem kolejnych nazwisk, z których trzy ostatnie są wyraźnie oddzielone od pozostałych. Oddzielenie wynika z zupełnie innego, niż reszta biogramów, charakteru informacji dotyczących trzech medyków - są to Personalia opracowane przez samych zainteresowanych, obszerne życiorysy pisane w pierwszej osobie. Także te dodane do wersji Ludwiga von Hammena biogramy pisane są pierwszą i drugą ręką. Spis treści pomija umieszczoną na stronie 181 króciutką notkę o Joannesie Jacobusie Weberskim (imię, nazwisko, data śmierci zapisane pierwszą ręką), najpewniej ze względu na odsyłacz do strony 207 (druga ręka), gdzie znajdują się Personalia J.J. Weberskiego.

Według opisu katalogowego rękopis obejmuje 158 kart. Jest to numeracja przyjęta przez osobę opracowującą rękopis, bowiem część słownika posiada własną paginację. Właściwy słownik Ludwiga von Hammena pisany jedną ręką (pierwsza) i uzupełniony dopiskami Valentina Schlieffa (druga ręka) ma strony numerowane atramentem w górnym rogu odpowiednio lewym dla stron parzystych i prawym dla stron nieparzystych. Paginacją opatrzono część rękopisu od s. 1 do s. 235 (pierwsza ręka s. 1-194, druga ręka s. 195-235). Numeracja ołówkiem, najpewniej wprowadzona przez bibliotekarza opracowującego manuskrypt, obejmuje karty dodane na początku do słownika Ludwiga von Hammena: k. 1-5 poprzedzają część biograficzną sporządzoną pierwszą ręką, po s. 235 następuje numeracja kart od s. 236 zrównanej z k. 118 konsekwentnie prowadzona do k. 158. Część kart jest pusta: strony 197-206, a także w sumie 79 stron między kolejnymi biogramami (s. 3, 8, 11, 12, 15, 16, 19, 20, 23, $24,28,31,32,35,36,39,40,44,47,48,52,55,56,59,63,64,67,68,71,72,75,76,79,80,83,84,88$, $91,92,95,96,99,100,103,108,111,112,116,119,120,124,127,131,132,136,139,140,143,144,147$, $148,155,156,163,164,167,168,171,172,175,176,179,180,183,188,191,192,195,196)$. Często puste strony oddzielają nie kolejne biogramy, lecz fragmenty tego samego hasła.

W przeważającej części jest to tekst łaciński. Po niemiecku spisane zostały Personalia J.J. Weberskiego, L. von Hammena i Efraima Furstloffa (s. 207-235), z wyjątkiem wykazu publikacji L. von Hammena opracowanego, jak w pozostałych biogramach, po łacinie. We właściwym słowniku pojedyncze zdania lub słowa niemieckie trafiają się w spisach publikacji lub jako nazwy własne. W tytułach prac omawianych lekarzy trafiają się też pojedyncze zdania lub słowa greckie. W spisach treści $\mathrm{i}$ indeksach często pomijane są końcówki łacińskie, a nazwiska $\mathrm{i}$ imiona podawane są w brzmieniu zbliżonym lub właściwym językowi niemieckiemu, np. Georgius - George, Fabricius oder Schmidt.

Karty 1-5 obejmują zacytowaną wyżej notatkę V. Schlieffa (k. 1), spis treści (k. 1-3) i alfabetyczny indeks nazwisk (k. 4-5) zapisany w trzech kolumnach na stronie.

Na stronach 1-235 znajdują się: właściwy słownik biograficzny i Personalia. Słownik zawiera uporządkowane chronologicznie informacje o 82 lekarzach gdańskich od drugiej ćwierci XVI do początku XVIII w. Układ nie jest przestrzegany rygorystycznie, chociażby z tego powodu, że nie każdy biogram zawiera informacje o dacie urodzin i śmierci. Często jedyne podane daty odnoszą się do roku publikacji danej pracy, pełnienia urzędu, zaślubin lub ukończenia studiów, bądź uzyskania przez danego lekarza stopnia doktora medycyny. Pierwszy biogram, dotyczący Johannesa Sommerfeldta, zawiera właśnie informację o pełnieniu przez niego funkcji fizyka miejskiego w $1541 \mathrm{r}$. i datę publikacji jego pracy w 1531 r. Ostatni biogram zapisany pierwszą ręką, dotyczący Benjamina Ewaldta, zawiera informacje o dacie urodzenia (1674 r.) i śmierci (1719 r.), a także wykaz publikacji z datami wydania konkretnych prac (22 tytuły wydrukowane w 1. 1697-1719). Zaś zamykający słownik (ostatni przed Personalia) biogram Joachimusa Cyrembergiusa (s. 197) jest dopisany drugą ręką i zaburza układ chronologiczny całości, bowiem jako pierwszą podaje datę promocji magisterskiej (1532 r.).

Większość biogramów zachowuje podział na informacje biograficzne i wykaz publikacji. Tylko w jednym przypadku podane jest nazwisko bez imienia (s. 54 - Weymerus, z informacją że to 
rówieśnik Joachimusa Oelhafiusa). Każde hasło rozpoczyna się od nowej strony. Brak jednak konsekwencji w wyróżnianiu spisu prac śródtytułem: Scripta (brak śródtytułu np.: s. 1, 14, 29, 74, 94, 165). Zdarza się, że prace są po prostu wyliczone pod biogramem, albo też informacja o publikacjach jest zawarta w notce biograficznej (np.: s. 90). W niektórych biogramach jest to zależne od ilości informacji, którymi dysponował pisarz kopiujący manuskrypt Ludwiga von Hammena, nierzadko bowiem pierwszą ręką zapisane jest imię, nazwisko, pochodzenie danego lekarza, a wszelkie inne dane są już dopisane przez Valentina Schlieffa (druga ręka; s. 30, 41, 54, 85, 138, 173, 178). Jedno hasło ogranicza się tylko do imienia i nazwiska (pierwsza ręka; s. 81 - Hermannus Fuchsius), najdłuższy z kolei jest biogram Joachimusa Pastoriusa (s. 150-154 i 157-160, s. 155-156 są puste). Tylko dziewięć haseł nie zawiera żadnych dopisków poczynionych drugą ręką (s. 10, 25, 45, 54, 84, 94, 170, 174, 190).

Kilka biogramów zawiera dodatkowe informacje: teksty epitafiów (s. 9, 18, 42, 97, 122, 150 kilka!), a w jednym przypadku treść pisma senatu gdańskiego do magistratu warszawskiego w sprawie uwięzienia Samuela Schönborniusa (s. 115).

Jak już wspomniano, strony 207-235 zajmują Personalia, czyli spisane po niemiecku autobiografie J.J. Weberskiego (s. 207-214), L. von Hammena (s. 215-226) i E. Furstloffa (s. 227-235). Są to odpisy poczynione pierwszą, a uzupełnione drugą ręką.

Karty 136-137 to Verzeichniss der Physicorum in Dantzig, czyli spisany drugą ręką wykaz lekarzy miejskich Gdańska uporządkowany chronologicznie wedle daty objęcia stanowiska. Obejmuje nazwiska 31 lekarzy, którzy pełnili funkcję miejskich medyków od 1532 do 1756 r. Spośród nich dziewiętnastu wymienionych zostało w słowniku biograficznym, dwunastu w Collectanea (patrz niżej). Poza imieniem i nazwiskiem podana jest także data śmierci, a przy niektórych nazwiskach dodatkowe skrótowe informacje (tytuł rozprawy stanowiącej podstawę uzyskania stopnia doktora, funkcje pełnione poza Gdańskiem, odniesienia bibliograficzne do innych pozycji traktujących o danej osobie).

Karty 138-151 zajmują Collectanea de Medicis Gedanensibus. Jest to spisany drugą ręką na papierze innego formatu i gramatury wykaz lekarzy stanowiący uzupełnienie słownika L. von Hammena. Tytuł: Collectanea... znajduje się na karcie 138, a sam wykaz rozpoczyna się od karty 139 podtytułem Series nonnullorum Medicorum Gedanensium. Obejmuje 106 numerowanych biogramów, spośród których 79 i 88 odnoszą się do tej samej osoby (Johannes Michael Bauer, pod nr 88 odsyłacz do nr 79). Chronologicznie wykaz ten obejmuje przełom XVII i XVIII w. - w pierwszym biogramie (Nathanael Gerlach) podana jest data śmierci - 1715 r., w ostatnim (Otto Joachim Willer) data uzyskania stopnia naukowego - 1747 r. Notki biograficzne uporządkowane chronologicznie są zbliżone do układu słownika. O związku między słownikiem a Collectanea świadczy umieszczone w notce 21 (Jacobus Bartholomaei) odesłanie do s. 133 słownika, na której znajduje się biogram tego lekarza. Wykaz ten posiada alfabetyczny indeks spisany na kartach $154 \mathrm{v}-156 \mathrm{v}$ w trzech kolumnach na stronie.

Bezpośrednio po k. 151 znajdują się dwie mniejszego formatu karteczki, z tego samego papieru co Collectanea, obie zapisane drugą ręką. Pierwsza z nich, większa, zatytułowana jest Recensio Doctorum Medicinae, qui Gedani vixerunt, vel ibidem nati sunt, quorum Parentes Verbi Divini Ministri fuerunt i zawiera zapisaną na obu stronach listę 32 nazwisk. Pierwsza część tej listy to tytułowy przegląd, numerowany kolejno od 1 do 27, choć nazwisk zapisanych jest 28. Ujęte pod numerem 9 nazwisko (Constantius Schmidt) zostało przekreślone, a numeracja poprawiona tak, by wykreślenie nie zaburzało ciągu. Na pierwszej stronie znajdują się numery od 1 do 20, na stronie drugiej od 21 do 27. Po numerowanym wykazie znajduje się nieczytelny śródtytuł, a pod nim cztery kolejne nazwiska już nienumerowane, z których pierwsze jest przekreślone. Daty umieszczone są tylko przy nr 27 i przy ostatnim nazwisku na stronie. Druga spośród dodatkowych kart zapisana dwustronnie drugą ręką. Odwrocie to przekreślone notatki (rachunki?) niezwiązane z materiałami biograficznymi. Pierwsza strona to notatki dotyczące siedmiu osób, których nazwiska nie pojawiają się we wcześniejszych częściach rękopisu.

Relacje między pierwszą a drugą ręką sugerują, że odpis słownika był przygotowywany od razu z myślą o uzupełnieniach. W przypadku biogramów pięciu lekarzy (J. Placotomus, B. Wagnerus, 
W. Welmnitius, N. Kleinfeld, J. Glaserus, D. Stolius) w tekście pisanym pierwszą ręką pojawiają się luki, uzupełniane częściowo przez drugą rękę, a dotyczące m.in. imion krewnych i powinowatych, liczby dzieci, daty urodzin lub śmierci, nazwy wykładanego przedmiotu. Trafiają się różnice w informacjach zapisanych przez pierwszą i drugą rękę, a dotyczących tego samego lekarza, np. rok śmierci Christianusa a Paulitza (s. 126: 1675 lub 1674 r.); fragmenty zapisane drugą ręką stanowią komentarz informacji zapisanych pierwszą ręką, np. w biogramie J. Mathesiusa (s. 22) odnośnie do pełnienia funkcji fizyka toruńskiego fragment dopisany drugą ręką brzmi: fallitur noster Autor, w biogramie T. Kellerthalera (s. 57) w sprawie pełnienia funkcji fizyka gdańskiego fragment dopisany drugą ręką brzmi: Physicum fuisse non inveni i w tej samej sprawie w biogramie T. Majusa (s. 62): Physicum tamen eum hic fuisse non memorat z przywołaniem pracy Athenae Gedanenses Ephraima Praetoriusa. W biogramie B. Fossiusa (s. 69) drugą ręką zapisano: Dubito hunc doctorem fuisse. Niekiedy drugą ręką zapisane są odesłania do innych części słownika, np. w biogramie J. Möllera (s. 165) po informacji o zaślubinach z wdową po Ch. a Paulitzu znajduje się odesłanie do biogramu tegoż lekarza; w biogramie S. Schönborniusa znajduje się odesłanie od skróconego opisu bibliograficznego zapisanego drugą ręką (s. 115) do zapisanego ręką pierwszą opisu pełnego na stronie 117; w biogramie J. Oelhafiusa (s. 50) drugą ręką zdublowano opis bibliograficzny jednej z prac i dopisano jednocześnie informację, że ten zapis to powtórzenie właśnie. Stosunkowo często poprawki lub uwagi poczynione drugą ręką przywołują na potwierdzenie inne teksty. W biogramie J. Pastoriusa autorstwo jednej z przypisanych mu prac zostaje poddane w wątpliwość we fragmencie zapisanym drugą ręką, w którym znajduje się powołanie na świadectwo samego J. Pastoriusa (s. 157): Hunc librum Pastorius pro suo non agnovit, a podobna uwaga powraca $\mathrm{w}$ tym samym biogramie na stronie 159 . W biogramie D. Beckhera (s. 86) jako źródło informacji o publikacjach tego lekarza wskazano we fragmencie zapisanym drugą ręką prace Andreasa oraz Christiana Friedricha Charitiusów ${ }^{23}$. W biogramie G. Segerusa (s. 145) we fragmencie zapisanym drugą ręką zestawione zostały informacje z dwóch różnych źródeł, z których pierwsze przypisuje G. Segerusowi autorstwo danej pracy, a drugie udowadnia błędność tej informacji. Przywołania innych prac stanowiących źródło informacji biograficznych zdecydowanie częściej zapisane są drugą ręką. Na około czterdzieści przywoływanych publikacji (w przypadku kilku tytułów nie ma pewności, czy w grę wchodzą różne prace, czy ten sam tytuł zapisany na różne sposoby) pierwszą ręką zapisane zostały odesłania do czterech tylko tytułów. Zdecydowana większość cytowań to pojedyncze przywołania, a tylko dziesięć prac przywoływanych jest częściej niż raz, najczęściej (szesnaście razy) Athenae Gedanenses E. Praetoriusa. W przypadku kilkunastu biogramów jako źródło informacji wskazane są mowy pogrzebowe, nierzadko drukowane. Poza źródłami drukowanymi przywoływane są także rękopisy, najczęściej listów, przechowywanych w bibliotece miejskiej ${ }^{24}$ lub w kolekcjach prywatnych ${ }^{25}$.

Podsumowując: przywoływany w niniejszym opracowaniu manuskrypt stanowi twór niejednolity. Nie jest jasne, czy pisany przez pierwszą rękę tekst, który wywodzi się najprawdopodobniej z manuskryptu Ludwiga von Hammena, w zamierzeniach autora miał stanowić uzupełnienie słownika Johannesa Antonidesa van der Lindena, co sugeruje wzmianka Henninga Wittego, czy też został sporządzony jako zapiski do osobnego dzieła. Nawet jeśli zamiarem autora było włączenie się w nowelizację dzieła swego starszego kolegi, to nie został on urzeczywistniony. Prawdopodobnie przyczyną tego stała się przedwczesna śmierć gdańszczanina. Mimo to poczynione przez niego notatki biograficzne, skopiowane przez pierwszą rękę, same w sobie stanowią cenne źródło do dziejów

\footnotetext{
23 A. Charitius, Commentatio historico literaria de viris eruditis Gedani ortis, Vittembergae Saxonum 1715 oraz Ch.

F. Charitius, Spicilegium ad D. Andreae Charitii Commentationem de viris eruditis Gedani ortis, Gedani 1729.

${ }^{24}$ W biogramie W. Misocasusa (s. 14, pierwsza ręka): Thema Genethliacon MS extat in Bibliotheca Publica.

${ }^{25}$ Drugą ręką poczynione uwagi w biogramach J. Pastoriusa (s. 160): In Bibliotheca Pauli Patris, Professoris Dantiscani adfuerunt Pastorii epistolae ad proceres Reipublicae Pol. [...]; w biogramie J. Glosemeyera (s. 184, 187) przywołanie i cytat $\mathrm{z}$ jego listu do Konstantego Ferbera; w biogramie J. Sommerfelda (s. 1) uwaga: patent e litteris Senatus ad Electorem Saxoniae et Magistratum Zwikauischem.
} 
medycyny gdańskiej. Manuskrypt stał się tym cenniejszy, że uzupełnił go oraz poszerzył Valentin Schlieff. Dlatego też wydaje się, że najbardziej poprawne jest przypisanie autorstwa rękopisu zarówno Ludwigowi von Hammenowi, jak i Valentinowi Schlieffowi. Rola tego ostatniego autora jest nie do przecenienia, gdyż nie tylko podjął się trudu kontynuacji zapisków, ale także, korzystając ze swego warsztatu historyka, poddał krytycznej analizie zastane informacje oraz czerpał $\mathrm{z}$ bogatszego zasobu źródeł niż jego poprzednik.

\section{Vitae medicorumGedanensium - a Manuscript from the Mid-eighteenth Century in the Collections of the Gdańsk Library of the Polish Academy of Sciences}

One of the most interesting archival sources for the history of medicine in Gdańsk is a manuscript in the Gdańsk Library of the Polish Academy of Sciences (Ms514), containing biographies of local physicians. Vitae medicorum Gedanensium, qui tum apudsuos tum apudexteros floruerunt originates from the library of V. Schlieff (1680-1750) and is attributed to the Gdańsk physician L. von Hammen (1651-1689). An analysis of the source, however, leads to the conclusion that this is a copy of the von Hammen manuscript in an unknown handwriting. The handwriting of the numerous later supplements is that of von Hammen, with Schlieff expanding the information in the biogrammes. The dictionary contains data about 82 Gdańsk physicians from the second quarter of the sixteenth century to the early eighteenth century, arranged in chronological order, and was not completed due to the death of the author. This is a valuable contribution to the history of medicine in Gdańsk, in particular after it was supplemented by Schlieff, who benefitted from a more copious range of sources than the one at the disposal of his predecessor.

Kontakt do autorów: blfsiek@gumed.edu.pl, szar@gumed@edu.pl 